\title{
1-Hydroxy Ethylidene 1,1-Diphosphonic Acid (HEDP) as a Corrosion Inhibitor for Aluminium
}

\author{
M. Hakeem ${ }^{1}$, S. Rajendran ${ }^{2}$ and Peter Pascal Regis ${ }^{3}$ \\ ${ }^{1}$ Department of Chemistry, Hajee Karutha Rowther Howdia College, Uthamapalayam, Theni District, Tamil \\ Nadu, India \\ sheikchandra@rediffmail.com \\ ${ }^{2}$ Department of Chemistry, RVS School of Engineering and Technology, Dindigul-624005, Tamil Nadu, India \\ srmjoany@sify.com \\ ${ }^{3}$ Associate Professor, Department of Chemistry, St. Joseph's College, Tiruchirappalli - 620002, \\ srisrielango@rediffmail.com
}

\begin{abstract}
The present study is to use 1-hydroxy ethylidene 1, 1-diphosphonic acid (HEDP) as corrosion inhibitor for aluminium in aqueous solution containing $60 \mathrm{ppm} \mathrm{Cl}^{-}$ion was chosen as the inhibitor. $\mathrm{Zn}^{2+}$ is selected as the synergist, as $\mathrm{Zn}^{2+}$ ions in association with HEDP inhibitor is considered environmental friendly inhibitor for aluminium corrosion in alkaline $(\mathrm{pH}=11)$ media. The environment chosen is aqueous solution containing $60 \mathrm{ppm} \mathrm{Cl}{ }^{-}$ions. To investigate the nature of the protective film, surface analytical techniques such as, Scanning Electron Microscopy (SEM), Atomic Force Microscopy (AFM) have been put to use in the present study. The formation of protective film has been confirmed using the electrochemical techniques such as polarization study and AC impedance spectral study. The above studies support the weight loss study.
\end{abstract}

Keywords: Aluminum; corrosion inhibition; HEDP; SEM; AFM

\section{Council for Innovative Research}

Peer Review Research Publishing System

Journal: Journal of Advances in Chemistry

Vol. 8, No. 1

editor@cirworld.com

www.cirjac.com, member.cirworld.com 


\section{Introduction}

At the start of Second World War, Al 0.05\% Copper alloys were used in marine and aircraft [1]. Al - Copper alloys are widely used because of their high strength to weight ratio; but they have relatively low corrosion resistance. Corrosion behaviour of B26S Al in lemon juice containing sweeteners such as glucose, sugar, saccharine and sorbitol was studied by Pandaya and Joshi [2]. Al has high resistance to corrosion in many environments due to the presence of protective surface film formed rapidly in air or in neutral aqueous solution [3]. However, in environments containing aggressive anions, primarily chlorides, the protective film gets locally damaged, and a corrosive attack takes place. Significant contributions have been made by Trabanelli [4] and Trasatti [5]. Despic et al., [6] and Radosevic et al., [7] have investigated the inhibition of corrosion of $\mathrm{Al}$.

$\mathrm{Al}$ and its alloys containing metals such as $\mathrm{In}, \mathrm{Mg}, \mathrm{Zn}$, and $\mathrm{Ga}$ have been found to be useful as anodes in alkaline batteries [8,9]. Corrosion of $\mathrm{Al}$ in $\mathrm{NaOH}$ solution has been prevented by addition of catechol and calcium oxide [10]. Due to environment-protection awareness, there is a move to make use of environmental friendly natural products as corrosion inhibitors.

Rajendran et al., have used an aqueous extract of onion, in controlling corrosion of $\mathrm{Al}$ in an aqueous solution containing $60 \mathrm{ppm}$ of $\mathrm{Cl}^{-}$at $\mathrm{pH} 11$ and $12 \mathrm{NaOH}$. Influence of $\mathrm{N}$-cetyl- $\mathrm{N}, \mathrm{N}, \mathrm{N}-$ trimethyl ammonium bromide, (CTAB), sodium sulphite, $\mathrm{Zn}^{2+}$ and immersion period on the inhibiting nature of onion extract has been investigated. The protective film has been analyzed by FTIR spectra [11]. Corrosion behaviour of Al in rain water containing garlic extract has studied at $\mathrm{pH} 11$ and 12. The influence of CTAB, sodium sulphite, $\mathrm{Zn}^{2+}$ and duration of immersion has also been investigated [12].

The present study is to use HEDP as a environmental friendly corrosion inhibitor for aluminium in aqueous solution containing $60 \mathrm{ppm} \mathrm{Cl}^{-}$ion and $\mathrm{Zn}^{2+}$ is selected as the synergist.

\section{Experimental}

\section{Preparation of the aluminium metal specimens}

Aluminium metal specimen of the dimensions $1.0 \times 4.0 \times 0.2 \mathrm{~cm}$ containing $95 \%$ pure aluminium was polished to mirror finish, degreased with trichloroethylene and used for weight - loss and surface examination studies. Aluminium metal rod encapsulated in Teflon with an exposed cross section of $1 \mathrm{~cm}^{2}$ area was used as the working electrode in potentiostatic polarization studies. The surface of the electrode was polished to mirror finish and degreased with trichloroethylene.

\section{Preparation of the stock solution}

$1 \mathrm{gm}$ of HEDP was dissolved in double distilled water, neutralized and then made upto $100 \mathrm{ml}$ in a standard measuring flask. One $\mathrm{ml}$ of this solution was diluted to $100 \mathrm{ml}$, which yields exactly $100 \mathrm{ppm}$ of HEDP.

\section{Determination of surface area of the specimens}

The length, breadth and the thickness of aluminium specimens and the radius of the holes were determined with the help of vernier calipers of high precision and the surface areas of the specimens were calculated.

\section{Weighing the specimens before and after corrosion} model.

The weights of the specimens before and after immersion were determined using a balance, Shimadzu AY62

\section{Determination of corrosion rate}

The weighed specimen, in triplicate were suspended by means of glass hooks in $100 \mathrm{ml}$ beakers containing 100 $\mathrm{ml}$ of aqueous solution containing $60 \mathrm{ppm} \mathrm{Cl}^{-}$of various concentrations of the inhibitor in the presence and absence of $\mathrm{Zn}^{2+}$ for 1 day of immersion. After 1 day of immersion the specimens were taken out, washed in running water, dried and weighed. From the change in weights of the specimen, corrosion rates were calculated using the following relationship.

\section{Weight loss method}

The percentage of inhibition efficiency was calculated using the following equation.

$$
I E \%=\frac{W_{1}-W_{2}}{W_{1}} \times 100
$$

$\mathrm{W}_{1}=$ corrosion rate in the absence of inhibitor and

$\mathrm{W}_{2}=$ corrosion rate in the presence of inhibitor

The corrosion rate was calculated using the following formula. 
Corrosion rate $(\mathrm{mm} / \mathrm{y})=[$ Loss in weight $(\mathrm{mg})] /\left[\right.$ Surface area of the specimen $\left(\mathrm{dm}^{2}\right)$ x period of immersion $($ day $\left.)\right] x$ $(0.0365 / \rho) \quad-----(2)$

$\rho$-density of the metal in $\mathrm{g} / \mathrm{cm}^{2}(7.86)$

\section{Potentiostatic polarization study}

This study was carried out using EG and G electrochemical impedance analyzer model 6310. A three electrode cell assembly was used. The working electrode was used as a rectangular specimen of aluminium with one face of the electrode of constant $1 \mathrm{~cm}^{2}$ area exposed. A saturated calomel electrode (SCE) was used as reference electrode. A rectangular platinum foil was used as the counter electrodes. A time interval of 5 to 10 min was given for the system to attain a steady state open circuit potential. The results such as Tafel slopes, $I_{\text {corr }}$ and $\mathrm{E}_{\text {corr }}$ values were calculated.

The working electrode and platinum electrode were immersed in aqueous solution containing $60 \mathrm{ppm}$ of $\mathrm{Cl}^{-}$in the absence and presence of inhibitor. Saturated calomel electrode was connected with the test solution through a salt bridge. Potential (E) vs log current (I) plots were then recorded. Corrosion potential $\left(E_{c o r r}\right)$ and Tafel slopes $b_{a}$ and $b_{c}$ were determined from $\mathrm{E}$ vs log I plots. Tangents were drawn on the cathodic and anodic polarization curves .From the point of intersection of the two tangents $I_{\text {corr }}$ and $E_{\text {corr }}$ were calculated.

\section{AC impedance measurements}

EG and $G$ electrochemical impedance analyzer model 6310 was used to record AC impedance measurements. The cell set up was the same as that used for polarization measurements. A time interval of 5 to 10 min was given for the system to attain a steady state open circuit potential. Then over this steady state potential, an A.C. potential of $10 \mathrm{mV}$ was superimposed. The AC frequency was varied from $100 \mathrm{kHz}$ to $100 \mathrm{mHz}$. The real part (Z') and imaginary part (Z') of the cell impedance were measured in ohms for various frequencies. The $R_{t}$ (charge transfer resistance) and $C_{d l}$ (double layer capacitance) values were calculated. $\mathrm{C}_{\mathrm{dl}}$ values were calculated using the following relationship.

where $f_{\max }=$ maximum frequency

$\mathrm{R}_{\mathrm{S}}=$ solution resistance

\section{Surface characterization studies}

The aluminium metal specimens were immersed in aqueous solution containing $60 \mathrm{ppm} \mathrm{Cl}^{-}$, as well as inhibitor solutions, for a period of one day. After 1 day, the specimens were taken out and dried. The nature of the film formed on the surface of the metal specimens was analyzed by various surface analysis techniques.

\section{Scanning Electron Microscopic studies (SEM)}

The aluminium metal specimen immersed in aqueous solution containing $60 \mathrm{ppm} \mathrm{Cl}^{-}$and in the inhibitor solution for a period of one day was removed, rinsed with double distilled water, dried and observed in a scanning electron microscope to examine the surface morphology. The surface morphology measurements of the aluminium were examined using Quanta $200 \mathrm{FEI}$, Netherland, GENESIS computer controlled scanning electron microscope.

\section{Atomic Force Microscopy characterization (AFM)}

The aluminium metal specimen immersed in aqueous solution containing $60 \mathrm{ppm} \mathrm{Cl}^{-}$and in the inhibitor solution for a period of one day was removed, rinsed with double distilled water, dried and subjected to the surface examination. The surface morphology measurements of the aluminium surface were carried by atomic force microscopy (AFM) using PicoSPM 2100 with the software version of Picoscan version 5.4. 


\section{Results and Discussion}

\section{Analysis of weight loss method}

Corrosion rate $(\mathrm{CR})$ of aluminium immersed in aqueous solution containing $60 \mathrm{ppm}$ of $\mathrm{Cl}^{-}$ions at $\mathrm{pH}=11$ for one day in the absence and presence of inhibitor 1-hydroxy ethylidene 1,1-diphosphonic acid (HEDP) has been evaluated and values are given in the Table 1(a) and Table 1(b). The inhibition efficiencies of HEDP are also given in these Tables. The inhibition efficiencies of the HEDP- $\mathrm{Zn}^{2+}$ systems as a function of concentration of HEDP are shown in Fig. 1.

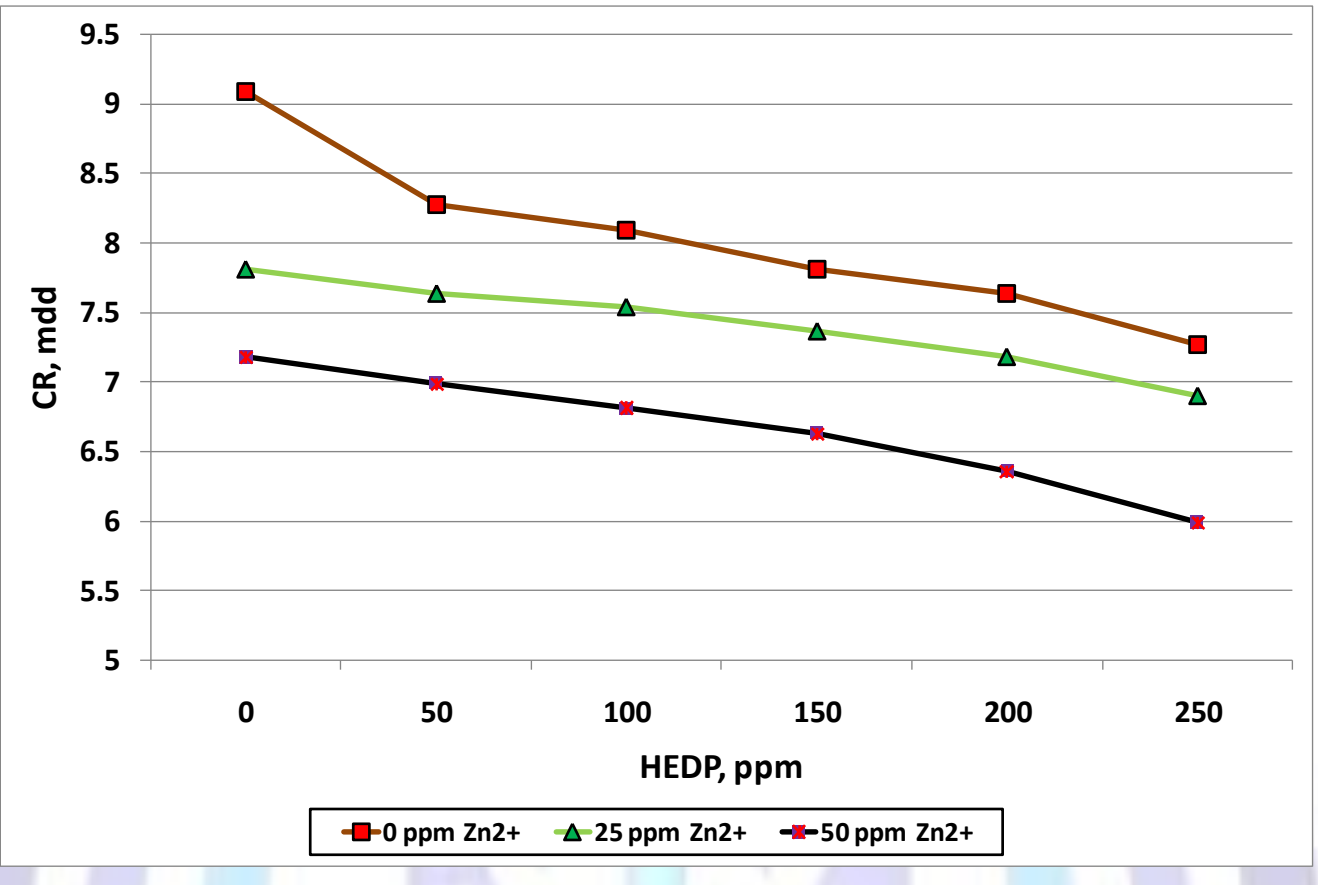

Fig.1: Corrosion rates (CR) of aluminium immersed in various test solutions

It is observed from Table 1 that HEDP shows some inhibition efficiencies and inhibition efficiency (IE) increases when the concentration increases. For example 50 ppm HEDP has 9 percent IE while 250 ppm HEDP has 20 per cent. This is due to the fact that as the concentration of HEDP increases, the protective film (probably aluminium HEDP complex) formed on the metal surface goes on increasing. That is the system passes from active region to passive region [13-15].

Table 1(a): Corrosion rates (CR) of aluminium immersed in aqueous solution containing $60 \mathrm{ppm} \mathrm{Cl}^{-}$ions in the absence and presence of inhibitor system at various concentration and the inhibition efficiencies (IE) obtained by weight loss method

Inhibitor system: 1-hydroxy ethylidene 1,1-diphosphonic acid $+\mathrm{Zn}^{2+}(0 \mathrm{ppm})$

Immersion period: 1 day

$\mathrm{pH}=11$

\begin{tabular}{|c|c|c|c|c|}
\hline $\mathrm{Cl}^{-} \mathrm{ppm}$ & $\begin{array}{c}\mathrm{HEDP} \\
\mathrm{ppm}\end{array}$ & $\mathrm{Zn}^{2+} \mathrm{ppm}$ & $\mathrm{CR}$ mdd & $\mathrm{IE} \%$ \\
\hline 60 & 0 & 0 & 9.09 & -- \\
\hline 60 & 50 & 0 & 8.27 & 9 \\
\hline 60 & 100 & 0 & 8.09 & 11 \\
\hline 60 & 150 & 0 & 7.81 & 14 \\
\hline 60 & 200 & 0 & 7.63 & 16 \\
\hline 60 & 250 & 0 & 7.27 & 20 \\
\hline
\end{tabular}


Table 1(b): Corrosion rates (CR) of aluminium immersed in aqueous solution containing $60 \mathrm{ppm} \mathrm{Cl}^{-}$ions in the absence and presence of inhibitor system at various concentration and the inhibition efficiencies (IE) obtained by weight loss method

Inhibitor system: HEDP $+\mathrm{Zn}^{2+}(50 \mathrm{ppm})$

Immersion period: 1 day

$\mathrm{pH}=11$

\begin{tabular}{|c|r|c|c|c|}
\hline $\mathrm{Cl}^{-} \mathrm{ppm}$ & $\begin{array}{c}\text { HEDP } \\
\mathrm{ppm}\end{array}$ & $\mathrm{Zn}^{2+} \mathrm{ppm}$ & $\mathrm{CR}$ mdd & $\mathrm{IE}$ \\
\hline 60 & 0 & 0 & 9.09 & -- \\
\hline 60 & 0 & 50 & 7.18 & 21 \\
\hline 60 & 50 & 50 & 6.99 & 23 \\
\hline 60 & 100 & 50 & 6.81 & 25 \\
\hline 60 & 150 & 50 & 6.63 & 27 \\
\hline 60 & 200 & 50 & 6.36 & 30 \\
\hline 60 & 250 & 50 & 5.99 & 34 \\
\hline
\end{tabular}

\section{Analysis of potentio dynamic polarization study $(\mathrm{pH}=11)$}

Polarization study has been used to confirm the formation of protective film formed on the metal surface during corrosion inhibition process [16-19]. If a protective film is formed on the metal surface, the linear polarization resistance value $(L P R)$ increases and the corrosion current value $\left(I_{\text {corr }}\right)$ decreases.

The potentiodynamic polarization curves of aluminium immersed in aqueous solution containing $60 \mathrm{ppm} \mathrm{Cl}^{-}$ions in the absence and presence of inhibitors are shown in Fig.2. The corrosion parameters are given in Table 2. When aluminium was immersed in aqueous solution containing $60 \mathrm{ppm} \mathrm{Cl}$ ions, the corrosion potential was $-1305 \mathrm{mV}$ vs SCE. When HEDP $(250 \mathrm{ppm})$ and $\mathrm{Zn}^{2+}(50 \mathrm{ppm})$ were added to the above system, the corrosion potential shifted to the noble side $-1236 \mathrm{mV}$ vs SCE. This indicates that a film is formed on the anodic sites of the metal surface. This film controls the anodic reaction of metal dissolution by forming $\mathrm{Al}^{3+}$-HEDP complex on the anodic sites of the metal surface. The formation of protective film on the metal surface is further supported by the fact that the anodic Tafel slope $\left(b_{a}\right)$ increases from $300 \mathrm{mV} / \mathrm{dec}$ ade to $349 \mathrm{mV} / \mathrm{dec}$ de. Further, the LPR value increases from $1.2463 \times 10^{5} \mathrm{ohm}_{\mathrm{cm}}^{2}$ to $1.6487 \times 10^{5}$ ohm cm $\mathrm{cm}^{2}$, the corrosion current decreases from $0.3402 \mu \mathrm{A} / \mathrm{cm}^{2}$ to $0.2563 \mu \mathrm{A} / \mathrm{cm}^{2}$. Thus, polarization study confirms the formation of a protective film on the metal surface.

For blank system, the value of current remains constant from potential -1.2 volt to 0.425 volt. At this volt, the film is broken. Hence the corrosion current increases suddenly. The break down potential is -0.425 volt. Similar observation is made for the inhibitor system also. Here the break down potential is -0.38 . The reason for the current remaining constant is due to the formation of passive film on the metal surface. Similar observation has been made [20,21] by R.D. Klassen and P.R.Roberge.

Table 2: Corrosion parameters of aluminium immersed in aqueous solution containing $60 \mathrm{ppm}$ of $\mathrm{Cl}^{-}$ions in the absence and presence of inhibitor system obtained from potentio dynamic polarization.

\begin{tabular}{|l|c|c|c|c|c|}
\hline \multicolumn{1}{|c|}{ System } & $\begin{array}{c}\mathrm{E}_{\text {corr }} \\
\mathrm{mV} \text { vs SCE }\end{array}$ & $\begin{array}{c}\mathrm{b}_{\mathrm{c}} \\
\mathrm{mV} / \mathrm{decade}\end{array}$ & $\begin{array}{c}\mathrm{b}_{\mathrm{a}} \\
\mathrm{mV} / \mathrm{decade}\end{array}$ & $\begin{array}{c}\mathrm{I}_{\text {corr }} \\
\mu \mathrm{A} / \mathrm{cm}^{2}\end{array}$ & $\begin{array}{c}\mathrm{LPR} \\
\text { ohm } \mathrm{cm}^{2}\end{array}$ \\
\hline $\begin{array}{l}\text { Aqueous solution } \\
\text { containing } 60 \mathrm{ppm} \\
\mathrm{Cl}^{-} \text {ions }\end{array}$ & -1305 & -144 & 300 & 0.3402 & $1.2463 \times 10^{5}$ \\
\hline $\begin{array}{l}\text { Aqueous solution } \\
\text { containing } 60 \mathrm{ppm} \\
\mathrm{Cl} \text { ions + } \mathrm{HEDP} \\
(250 \mathrm{ppm})+\mathrm{Zn}^{2+}(50\end{array}$ & -1236 & -134 & 349 & 0.2563 & $1.6487 \times 10^{5}$ \\
$\mathrm{ppm})$ & & & & & \\
\hline
\end{tabular}




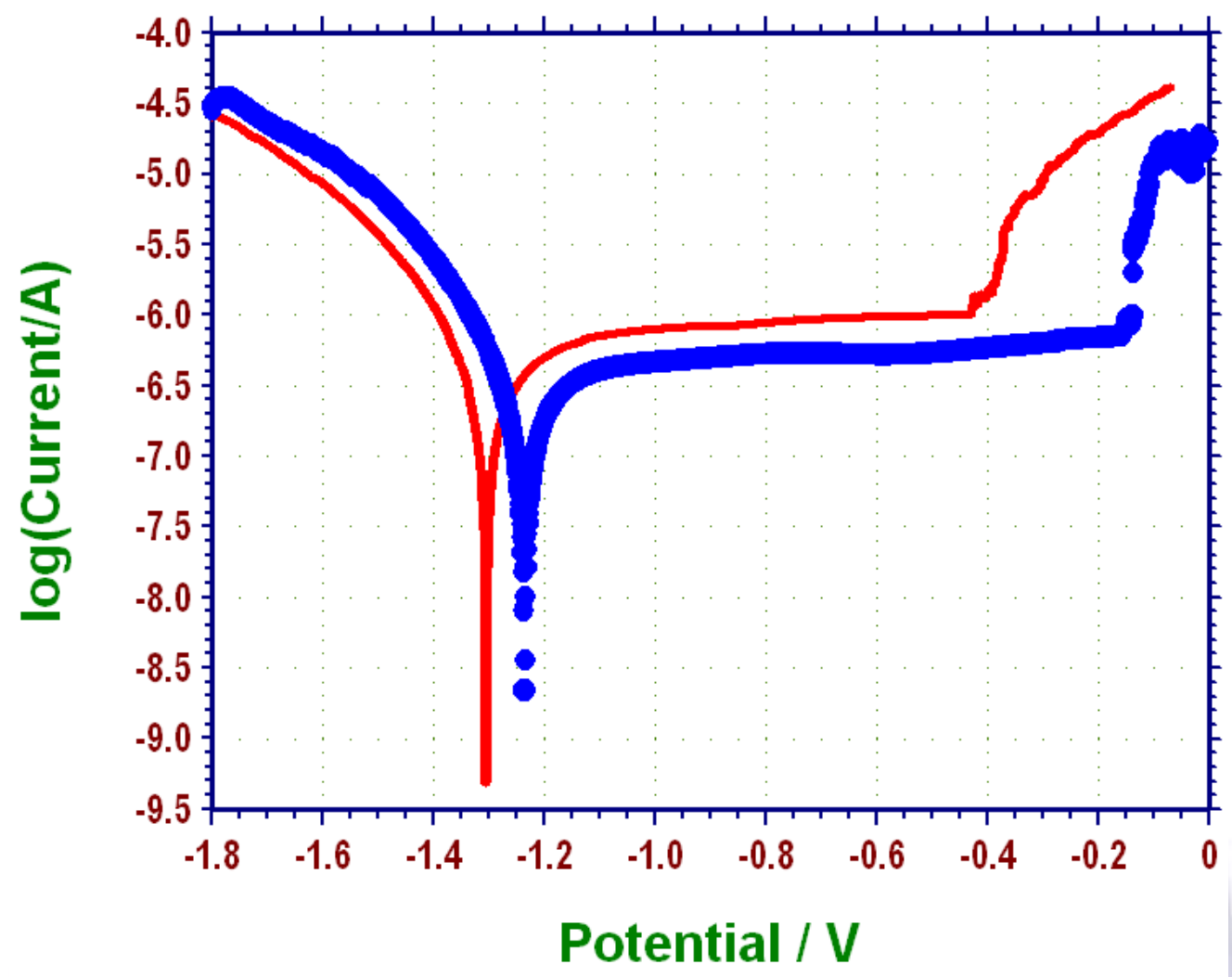

Fig. 2 : Polarization curves of aluminium metal immersed in various test solutions

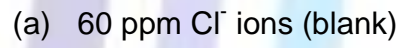

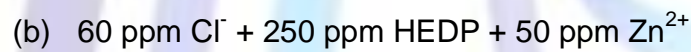

\section{Analysis of AC impedance spectra}

AC impedance spectra (electrochemical impedance spectra) have been used to confirm the formation of protective film on the metal surface [22-26]. If a protective film is formed on the metal surface, charge transfer resistance $\left(R_{t}\right)$ increases, double layer capacitance value $\left(C_{d l}\right)$ decreases and the impedance log $(z / o h m)$ value increases. The $A C$ impedance spectra of aluminium immersed in aqueous solution containing $60 \mathrm{ppm} \mathrm{Cl}^{-}$ions in the absence and the presence of inhibitors (HEDP- $\mathrm{Zn}^{2+}$ ) are shown in Fig.3 (Nyquist plots). The AC impedance parameters namely charge transfer resistance $\left(\mathrm{R}_{\mathrm{t}}\right)$ and double layer capacitance $\left(\mathrm{C}_{\mathrm{dl}}\right)$ derived from Nyquist plots are given in Table 3 . The impedance $\log (\mathrm{z} / \mathrm{ohm})$ values derived from Bode plots are also given in Table 3.

It is observed that when the inhibitors HEDP $(250 \mathrm{ppm})+\mathrm{Zn}^{2+}(50 \mathrm{ppm})$ are added, the charge transfer resistance $\left(R_{t}\right)$ increases from $5979 \Omega \mathrm{cm}^{2}$ to $6293 \Omega \mathrm{cm}^{2}$. The $C_{d l}$ value decreases from $8.52 \times 10^{-4} \mathrm{~F} / \mathrm{cm}^{2}$ to $8.1045 \times$ $10^{-4} \mathrm{~F} / \mathrm{cm}^{2}$. These results lead to the conclusion that a protective film is formed on the metal surface. Equivalent circuit diagram of Aluminium immersed in various test solutions is shown in Scheme 1.

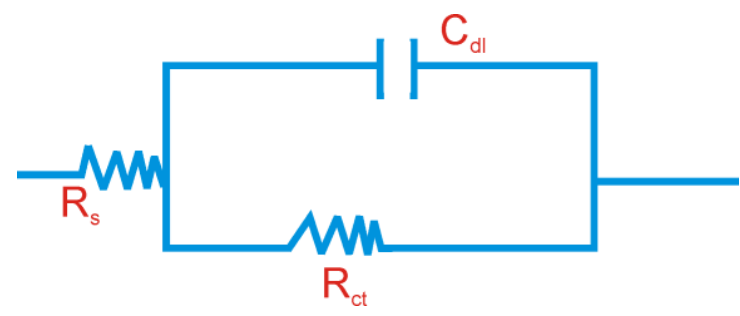

Scheme 1: Equivalent circuit diagram 


$\begin{array}{lll}\mathrm{R}_{\mathrm{S}} & = & \text { Solution resistance } \\ \mathrm{R}_{\mathrm{ct}} & = & \text { Charge transfer resistance } \\ \mathrm{C}_{\mathrm{dl}} & = & \text { double layer capacitance }\end{array}$

In presence of inhibitor, the phase angle value increases from $48^{\circ}$ to $52^{\circ}$. This is due to formation of protective film.

Table 3 : Corrosion parameters of aluminium immersed in aqueous solution containing $60 \mathrm{ppm} \mathrm{Cl}^{-}$ions in the absence and presence of inhibitor system obtained from $A C$ impedance spectra $(\mathrm{pH}=11)$

\begin{tabular}{|l|c|c|c|}
\hline \multirow{2}{*}{ System } & \multicolumn{2}{|c|}{ Nyquist plot } & Bode plot \\
\cline { 2 - 4 } & $\begin{array}{c}\mathrm{R}_{\mathrm{t}} \mathrm{ohmm} \\
\mathrm{cm}^{2}\end{array}$ & $\mathrm{C}_{\mathrm{dl}} \quad \mu \mathrm{F} / \mathrm{cm}^{2}$ & $\begin{array}{c}\text { Impedance value } \\
\text { log(z/ohm) }\end{array}$ \\
\hline $\begin{array}{l}\text { Aqueous solution containing } \\
60 \text { ppm Cl ions }\end{array}$ & 5979 & $8.52 \times 10^{-4}$ & 3.841 \\
\hline $\begin{array}{l}\text { Aqueous solution containing } \\
60 \text { ppm } \mathrm{Cl}^{-} \text {ions + HEDP }(250 \\
\text { ppm })+\mathrm{Zn}^{2+}(50 \text { ppm) }\end{array}$ & 6293 & $8.1045 \times 10^{-4}$ & 3.872 \\
\hline
\end{tabular}

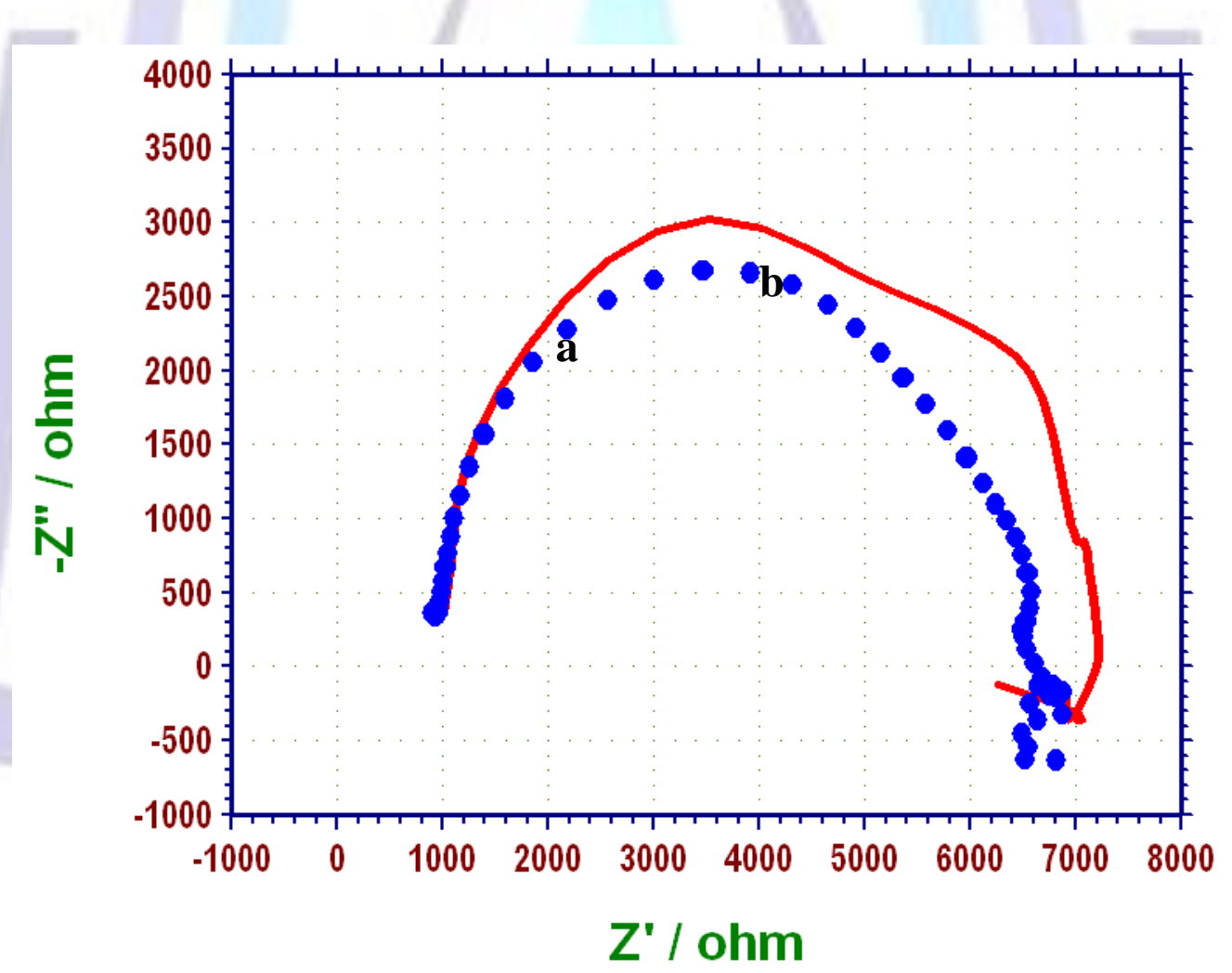

Fig.3: AC impedance spectra of aluminium metal immersed in various test solution (Nyquist plot)

(a) 60 ppm $\mathrm{Cl}^{-}$ions (blank)

(b) $60 \mathrm{ppm} \mathrm{Cl}^{-}$ions $+250 \mathrm{ppm}$ of HEDP $+50 \mathrm{ppm}$ of $\mathrm{Zn}^{2+}$ 


\section{SEM Analysis of Metal Surface}

SEM provides a pictorial representation of the surface. To understand the nature of the surface film in the absence and presence of inhibitors and the extent of corrosion of aluminium, the SEM micrographs of the surface are examined [27-30].

The SEM images of magnification (X 1000) of aluminium specimen immersed in aqueous solution containing 60 ppm of $\mathrm{Cl}^{-}$ions for 1 day in the absence and presence of inhibitor system are shown in Fig.4 (a,b).

The SEM micrographs of aluminium metal surface immersed in aqueous solution containing $60 \mathrm{ppm}$ of $\mathrm{Cl}^{-}$ions (Fig.4(a)) shows the roughness of the metal surface which indicates the highly corroded area of aluminium metal in aqueous solution containing $60 \mathrm{ppm}$ of $\mathrm{Cl}^{-}$ions. However Fig.4 (b) indicates that in the presence of inhibitor (250 ppm HEDP and $50 \mathrm{ppm} \mathrm{Zn}^{2+}$ ) the rate of corrosion is suppressed, as can be seen from the decrease of corroded areas. The decrease in corrosion is due to the formation of insoluble complex on the surface of the metal [31-33]. In the presence of HEDP and $\mathrm{Zn}^{2+}$, the surface is covered by a thin layer of inhibitors which effectively controls the dissolution of aluminium metal.

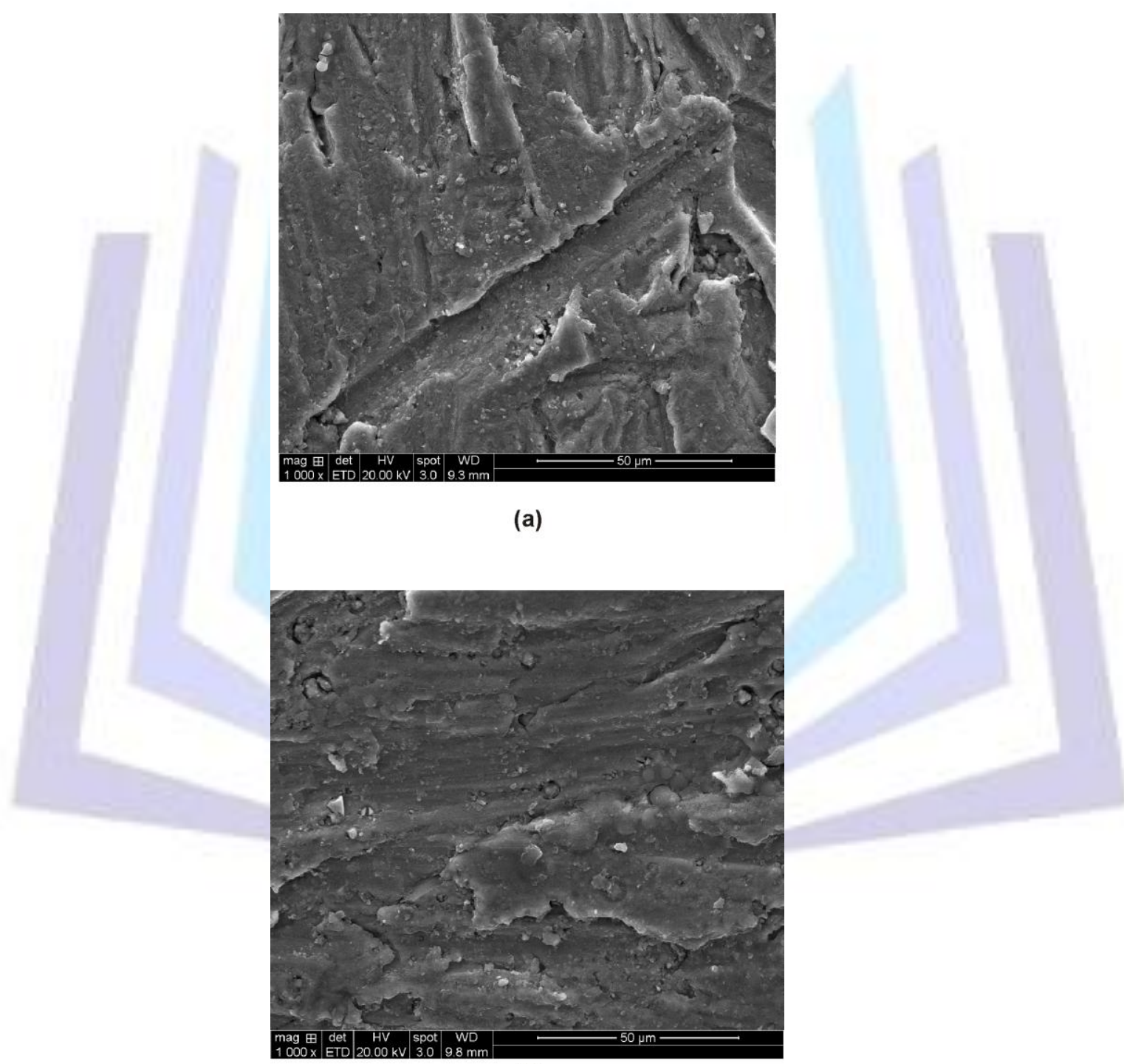

(b)

Fig.4: SEM analysis of

(a) Aluminium metal immersed in aqueous solution containing 60 ppm of $\mathrm{Cl}^{-}$(blank); Magnification $X 1000$

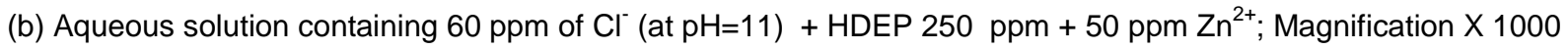




\section{Atomic Force Microscopy Characterization}

Atomic force microscopy is a powerful technique for gathering of roughness statistics from a variety of surfaces [34]. AFM is becoming an accepted method of roughness investigation [35-39].

All atomic force microscopy images were obtained in a VECCO Lab incorporation. AFM instrument operating in contact mode in air. The scan size of all the AFM images are $05 \mu \mathrm{m} \times 05 \mu \mathrm{m}$ areas at a scan rate of $6.68 \mu \mathrm{m} / \mathrm{second}$.

The two dimensional (2D), three dimensional (3D) AFM morphologies and the AFM cross-sectional profile for polished aluminium metal surface (reference sample), aluminium metal surface immersed in aqueous solution containing $60 \mathrm{ppm}$ of $\mathrm{Cl}^{-}$ions (blank sample) and aluminium metal surface immersed in aqueous solution containing $60 \mathrm{ppm}^{-1}$ containing the formulation of HEDP 250 ppm and $\mathrm{Zn}^{2+} 50$ ppm are shown as Fig.5. (a,d,g), (b,e,h), (c,f,i) respectively.

\section{Root- mean-square roughness, average roughness and peak-to-valley value}

AFM image analysis was performed to obtain the average roughness, $R_{a}$ (the average deviation of all points roughness profile from a mean line over the evaluation length), root-mean-square roughness, $R_{q}$ (the average of the measured height deviations taken within the evaluation length and measured from the mean line) and the maximum peakto-valley $(\mathrm{P}-\mathrm{V})$ height values (largest single peak-to-valley height in five adjoining sampling heights). $\mathrm{R}_{\mathrm{q}}$ is much more sensitive than $R_{a}$ to large and small height deviations from the mean.

Table 4 is the summary of the average roughness $\left(R_{a}\right)$, rms roughness $\left(R_{q}\right)$ maximum peak-to-valley height $(P-V)$ value for aluminum metal surface immersed in different environments.

The value of $R_{R M S}, R_{a}$ and $P-V$ height for the polished aluminium metal surface (reference sample) are $4 \mathrm{~nm}, 3$ $\mathrm{nm}$ and $50 \mathrm{~nm}$ respectively, which shows a more homogeneous surface, with some places in which the height is lower than the average depth. Fig.5 $(\mathrm{a}, \mathrm{d}, \mathrm{g})$ displays the uncorroded metal surface. The slight roughness observed on the polished aluminium metal surface is due to atmospheric corrosion. The rms roughness, average roughness and $\mathrm{P}-\mathrm{V}$ height values for the aluminium metal surface immersed in aqueous solution containing $60 \mathrm{ppm}$ of $\mathrm{Cl}^{-}$ions are $37 \mathrm{~nm}, 29$ $\mathrm{nm}$ and $115 \mathrm{~nm}$ respectively. These data suggest that aluminium metal surface immersed in aqueous solution containing $60 \mathrm{ppm}$ of $\mathrm{Cl}^{-}$ions has a greater surface roughness than the polished metal surface. Which shows that the unprotected aluminium metal surface is rougher and is due to the corrosion of the aluminium metal in aqueous solution containing 60 ppm of $\mathrm{Cl}^{-}$. Fig.5 (b, e, h) displays the corroded metal surface with few pits.

The presence of $250 \mathrm{ppm}$ of HEDP and $50 \mathrm{ppm}$ of $\mathrm{Zn}^{2+}$ in aqueous solution containing $60 \mathrm{ppm}$ of $\mathrm{Cl}^{-}$ions reduces the $R_{q}$ value decrease from $37 \mathrm{~nm}$ to $20 \mathrm{~nm}$ and the average roughness value is significantly reduced to $15 \mathrm{~nm}$ when compared with $29 \mathrm{~nm}$ of aluminium metal surface immersed in aqueous solution containing $60 \mathrm{ppm}$ of $\mathrm{Cl}^{-}$ions. The maximum peak-to-valley height also was reduced to $78 \mathrm{~nm}$ from $115 \mathrm{~nm}$. These parameters confirm that the surface appears smoother. The smoothness of the surface is due to the formation of a compact protective film of $\mathrm{Al}^{3+}$. HEDP complex and $\mathrm{Zn}(\mathrm{OH})_{2}$ on the metal surface thereby inhibiting the corrosion of aluminium metal. Fig.5 (c,f,i) displays smooth surface of the aluminium metal due to the formation of protective film.

Also the above parameters observed are somewhat greater than the AFM data of polished metal surface which confirms the formation of the film on the metal surface, which is protective in nature.

Table 4. AFM data for aluminium surface immersed in inhibited and uninhibited environments

\begin{tabular}{|l|c|c|c|}
\hline \multicolumn{1}{|c|}{ Samples } & $\begin{array}{c}\text { RMS }\left(\mathrm{R}_{\mathrm{q}}\right) \\
\text { Roughness } \\
(\mathrm{nm})\end{array}$ & $\begin{array}{c}\text { Average }\left(\mathrm{R}_{\mathrm{a}}\right) \\
\text { Roughness }(\mathrm{nm})\end{array}$ & $\begin{array}{c}\text { Maximum peak- } \\
\text { to-valley height } \\
(\mathrm{nm})\end{array}$ \\
\hline $\begin{array}{l}\text { Polished aluminium metal } \\
\text { (control) }\end{array}$ & 4 & 3 & 50 \\
\hline $\begin{array}{l}\text { Aluminium metal immersed in } \\
\text { aqueous solution containing } \\
60 \text { ppm Cl- ions }\end{array}$ & 37 & 29 & 115 \\
\hline $\begin{array}{l}\text { Aluminium metal immersed in } \\
\text { aqueous solution containing } \\
60 \mathrm{ppm} \mathrm{Cl} \text { ions }+ \text { HEDP 250 } \\
\mathrm{ppm}+\mathrm{Zn}^{2+} 50 \text { ppm }\end{array}$ & 20 & 15 & 78 \\
\hline
\end{tabular}




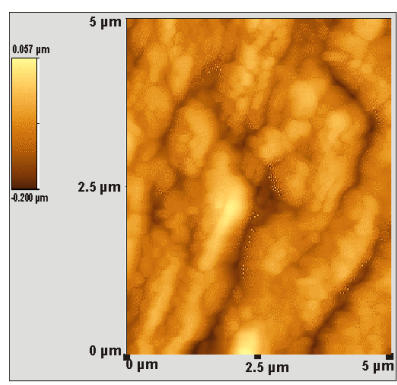

(a)

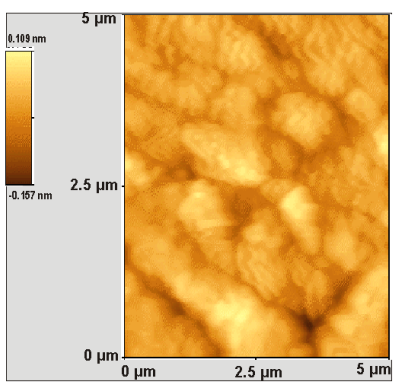

(b)

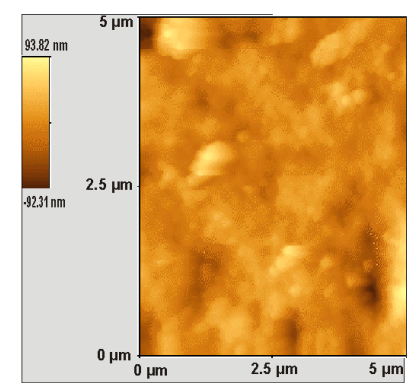

(c)

2D AFM images of the surface of

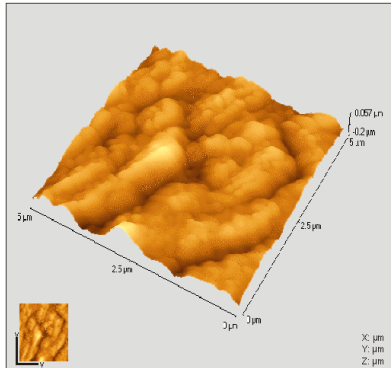

(d)

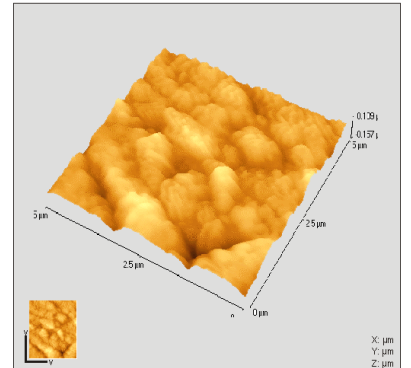

(e)

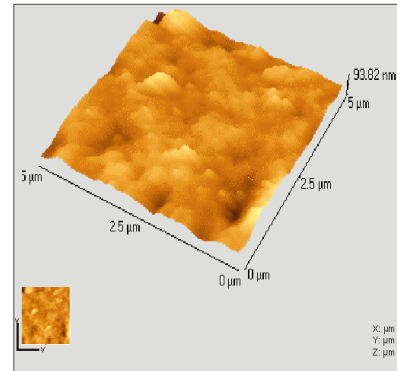

(f)

3D AFM images of the surface of

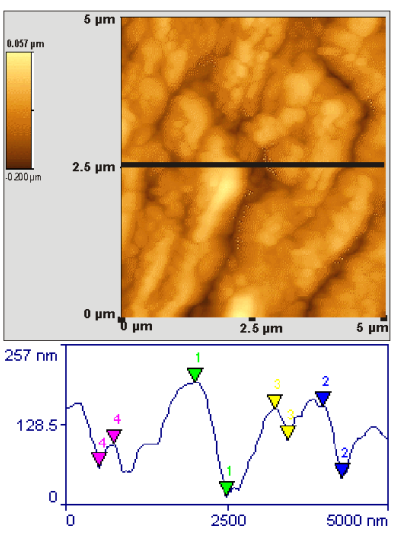

(g)

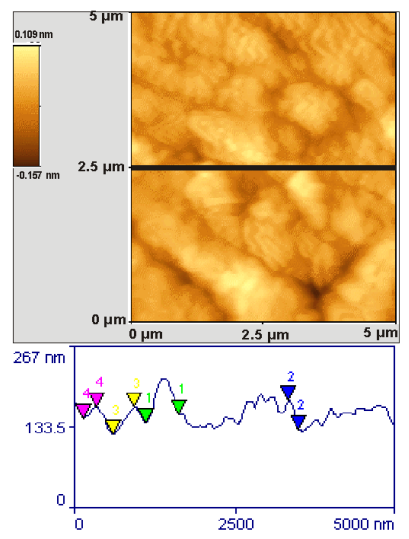

(h)

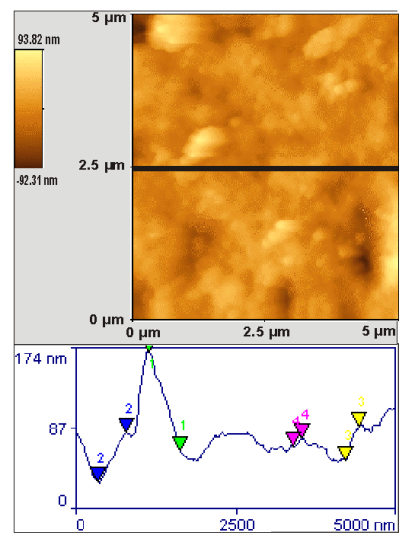

(I)

The cross sectional profile which are corresponding to as shown broken lines in AFM images of the surface of

Fig. 5: AFM images of the surface of

(a)(d)(g) Polished aluminium metal (control)

(b)(e)(h) Aluminium metal immersed in aqueous solution containing 60 ppm Cl- ions

(c)(f)(i) Aluminium metal immersed in aqueous solution containing 60 ppm Cl- ions +250 ppm of HEDP +50 ppm of Zn2+ 


\section{Conclusions}

- HEDP inhibitor exhibit synergism with $\mathrm{Zn}^{2+}$ ions at various concentrations in the corrosion inhibition of aluminium metal in an aqueous solution containing $60 \mathrm{ppm} \mathrm{Cl}^{-}$at $\mathrm{pH}=11$.

* The protective film formed on the surface of the aluminium metal in an aqueous solution containing $60 \mathrm{ppm} \mathrm{Cl}^{-}$in the presence of synergistic inhibitors was stable.

* Polarization study shows that the effective inhibitor $\mathrm{Zn}^{2+}$ system function as anodic inhibitors controlling the anodic reaction predominantly and to some extent controls the cathodic reaction.

* The SEM and AFM image indicates the possibility of formation of the film on the surface and gives the surface morphology.

* Based on the weight loss method, electro chemical studies and spectroscopic techniques a suitable mechanism has been proposed for the efficient synergistic inhibitor and $\mathrm{Zn}^{2+}$ system.

\section{Acknowledgment}

The authors are thankful to their respective management and UGC, New Delhi for their encouragement and support. Mr.S. Elango for his computer aided design and help.

\section{References}

[1]. V. Ramesh Saliyan and Airody Vasudeva Adikari, Transactions of the SAEST, 41 (2006) 88-93.

[2]. J.M. Pandya and S.D. Joshi, Proc. National Symposium on Electrochemistry in Aerospace Systems, ISRO Satellite Centre Centre, Bangalore, India. Nov.20 \& 21, 1998, P.97.

[3]. Susai Rajendran, S.Muthulakhsmi, R.Rajeswari and A.Vijitha, J.Electrochem Soc, India. 54(2) (2005) 50.

[4]. G.Trabanelli, “Corrosion Mechanism”, F.Mansfeld Dekker Inc., New York (1987) p.119.

[5]. S.Trasatti, Electrochem. Acta., 37, (1998)2137.

[6]. A.Despic, J.Radosevic and M.Kilskic, Proc. $7^{\text {th }}$ Europ. Symp. Corrosion Inhibitors, Univ. Ferrara, Ferrara, Italy, 2 (1990) 1119.

[7]. J.Radosevic, M. Kiliskic and A.Despic, J.Appl. Electrochem., 22 (1992) 649.

[8]. J.Radosevic, M. Kiliskic, L.J. Alijnovic and S.Vuko, Pro. $8^{\text {th }}$ Europ. Symp. Corrosion Inhibitors, 2 (1995) 817.

[9]. S.Zaromb, "Power Systems for Electric Vehicles", A symposium sponsored by U.S. Department of HEW, New York, (April 1967) 225.

[10].T. Jayaraj, C. Raja and V.Violet Dhayabaram, Transaction of the SAEST, 37(1) (2002) 25.

[11].S. Rajendran, S. Muthulakshmi, R. Rajeswari and A. Vijitha, J. Electrochemical Society, India, 54 (2005) 50.

[12].S. Lakshmi Priya, A. Chitra, S. Rajendran and K. Anuradha, Surface Engineering, 21(3) (2005) 229.

[13].J.H. Morgan, "Cathodic Protection", The Maxmillion Company, New York (1960)

[14].O.L.Riggs and C.E.Locke, "Anodic Protection", Plenum Press, New York (1981).

[15].S.S.Elegamy and W.A. Badaway, J.Appl. Electro.Chem., 34 (2004) 1153.

[16].S. Muralidharan, K.L.N. Phani, S. Pitchumani, S. Ravichandran, and S.V.K. Iyer, J Electrochem. Soc., 142 (1995) 1478.

[17].S.S.A. Elrehirn, S.A.M. Refaey, F. Taha, M.B. Saleh and R.A. Ahmed, J Appl. Electrochem., 31 (2001) 429.

[18].S.S. Begum, R. Subramanian, V. Lakshrninavayan and S.M. Mayanna,Ind. J Chem. Techno!., 8 (2001) 463.

[19].G.P. Sahu and S.C. Lavalve, Asian J Chem., 17 (2005) 259.

[20].R.D. Klassen and P.R. Roberge, J Appl. Electrochem., 34 (2004) 723.

[21].R. LeRoy, Corr., 29 (1973) 272, \& 31 (1975) 173.

[22].D.D. MacDonald and M.C.H.McKubre "Electrochemical impedance techniques in corrosion, "Proc. ASTM (1981) 110.

[23].P.R. Roberge and V.S. Sastri, Corr., 50 (1994) 744.

[24].P.R. Roberge and V.s. Sastri, Br. Corr. J, 29 (1994) 405.

[25].J.L. Polo, E. Cano and J.M. Bastidas, Corr. Prevo \& Control, 51 (2004) 55. 
[26].H. AshassiSorkhabi and N. GhalebsazJeddi, Matls. Chem. \& Phy., 92 (2005) 480.

[27].I. Sekine and Y. Hirakawa, Corrosion, 42 (1986) 272.

[28].A.S. Algaber, E.M.El. Nemma and M.M. Saleh, Matls. Chem. \& Phy., 86 (2004) 26.

[29].K.E. Kurtis, W. Meyer Isle and P.J.M. Monteiro, Corr. Sci., 42 (2000) 1327.

[30].S. Ramesh and S. Rajeswari, Corrosion Science, 47 (2005) 151.

[31].G. Gunasekaran and L.R. Chauhan, Electrochim. Acta, 49 (2004) 4387

[32].S. Sharma and R.S. Chaudhary, Bull. Electrochem. 16 (2000) 267.

[33].S.A.M. Rafaly, Appl. Surf. Sci., 157 (200) 199.

[34].P. Schmutz and G.S. Frankel, J. of the electro. Chem. Society, 146(12) (1999) 4461-4472.

[35].V.B.Sing and A. Gupta, Ind. J. Chem. Technol., 12 (2005) 347.

[36].A. A. Valeria, A.M. Chiorcea Paquim, A.Cavaleiro and M.A. Christopher Brett., Corr. Sci., 47 (2005) 2871.

[37].R.J. Holness, G. Williams, D.A. Worsley and H.N. Acmurray, J. Electrochem. Soc., 152 (2005) 137.

[38].M.L. Zheludkevich, K.A. Yasakau, S.K. Poznyak and M.G.S.Ferreira Corrosion Science, 47(12) (2005) 33683383.

[39].Tianhe, Yuanchaowang, Yijian Zhang, QunIV, Tugen Xu and Tao Liu, Corrosion Science, 51(8) (2009) 17571761. 